\title{
SFCOMPO DATABASE OF SPENT NUCLEAR FUEL ASSAY DATA - THE NEXT FRONTIER
}

\author{
Germina Ilas $^{1}$, Ian Gauld ${ }^{1 *}$, Pedro Ortego ${ }^{2}$, and Shuichi Tsuda ${ }^{3}$ \\ ${ }^{1}$ Oak Ridge National Laboratory \\ Oak Ridge, TN 37831, USA \\ ${ }^{2}$ SEA Ingeniería y Análisis de Blindajes S.L. \\ Madrid, Spain \\ ${ }^{3}$ Organisation for Economic Co-operation and Development/Nuclear Energy Agency \\ Boulogne-Billancourt, France
}

ilasg@ornl.gov,gauldic@gmail.com,p.ortego@seaingenieria.es,shuichi.tsuda@oecd-nea.org

\begin{abstract}
SFCOMPO is the world's largest database for measured spent nuclear fuel assay data. An international effort coordinated by the Nuclear Energy Agency (NEA) resulted in a significant expansion of the database and its release online in 2017 as a downloadable application. The SFCOMPO Technical Review Group (TRG) was recently formed under the direction of NEA's Nuclear Science Committee/Working Party on Nuclear Criticality Safety and was mandated to maintain and further coordinate the development of SFCOMPO. This TRG is currently focused on (1) critical evaluation of the experimental assay data by independent experts and (2) development of benchmarks and benchmark models that can be applied to validate burnup codes. This will improve the quality and documentation of the experimental datasets and enable their use by the international community to support code validation for design and safety analysis of spent nuclear fuel transportation, storage, and repository applications. It follows the precedent and draws on the experience gained from similar NEA efforts in the International Reactor Physics Experiment Evaluation Project and the International Criticality Safety Benchmark Experiment Project. Ongoing SFCOMPO evaluations have served as a test bed to develop templates for documenting evaluations, develop review guidance, improve approaches for a global uncertainty analysis, and devise a strategy focused on providing practical information of highest value to the user community. The current effort, status, and associated challenges are discussed.
\end{abstract}

KEYWORDS: SFCOMPO, spent nuclear fuel, benchmark, isotopic assay data

\footnotetext{
${ }^{*}$ Currently retired.

Notice: This manuscript has been authored by UT-Battelle, LLC, under contract DE-AC05-00OR22725 with the US Department of Energy (DOE). The US government retains and the publisher, by accepting the article for publication, acknowledges that the US government retains a nonexclusive, paid-up, irrevocable, worldwide license to publish or reproduce the published form of this manuscript, or allow others to do so, for US government purposes. DOE will provide public access to these results of federally sponsored research in accordance with the DOE Public Access Plan (http://energy.gov/downloads/doe-public-access-plan).
} 


\section{INTRODUCTION}

SFCOMPO is the world's largest database for measured spent nuclear fuel isotopic assay data [1]. An international effort coordinated by the Organisation for Economic Co-operation and Development (OECD)/ Nuclear Energy Agency (NEA) resulted in a significant expansion of the database and its release online in 2017 as a downloadable application [2]. The SFCOMPO Technical Review Group (TRG) was recently formed under the direction of NEA's Nuclear Science Committee/Working Party on Nuclear Criticality Safety (WPNCS) and was mandated to maintain and further coordinate the development of the database [3]. This TRG transitioned from the former NEA Expert Group on Assay Data for Spent Nuclear Fuel (EGADSNF). The group's focus has changed from data collection and database development to data maintenance, review, and improvement.

The SFCOMPO TRG is currently focused on (1) critical evaluation of the data by independent experts and (2) development of benchmarks and benchmark models. This process will improve the quality and documentation of the experimental datasets and enable their use by the international community to support code validation for design and safety analysis of spent fuel transportation, storage, and repository applications. The evaluation process follows precedent and draws on the experience gained from similar NEA activities in the International Reactor Physics Experiment Evaluation Project (IRPhEP) [4,5] and the International Criticality Safety Benchmark Experiment Project (ICSBEP) [6].

Ongoing SFCOMPO evaluations have served as a test bed to develop templates for documenting evaluations, develop an independent reviewer's guidance, improve approaches for a global uncertainty analysis, and devise a strategy focused on providing practical information of highest value to the community. The current effort, status, and associated challenges are presented herein.

\section{SFCOMPO DATABASE}

\subsection{Database Evolution}

The first version of the SFCOMPO database was compiled by the Japan Atomic Energy Research Institute (JAERI) in the early 1990s. It included tables of isotopic measurement data for spent nuclear fuel samples selected from fuel that had been irradiated in two types of reactors: pressurized water reactors (PWRs) and boiling water reactors (BWRs). In 2001, when SFCOMPO was transferred from JAERI to NEA, it contained a series of web pages listing measurement data for 246 samples selected from fuel irradiated in seven PWRs and seven BWRs. Since then, the database has expanded significantly as a result of the international community's concerted effort led by the EGADSNF. This group of experts in spent nuclear fuel modeling and simulation and radiochemistry has identified many additional published experimental data, and in 2013, they began developing a new, modern database with a standardized format and improved accessibility [7,8]. This effort culminated with the release in 2017 of SFCOMPO 2.0 as a downloadable NEA Java application.

\subsection{Current Status}

SFCOMPO 2.0 contains isotopic experimental data for 750 samples selected from fuel irradiated in 44 reactors, with over 22,000 measurement entries for more than 90 isotopes important to a large variety of spent fuel applications. In addition to PWR and BWR measurements for UOX spent fuel, the database now includes experimental data for other reactor designs, including AGR, CANDU, MAGNOX, RBMK, VVER-440, and VVER-1000 [7], as well as MOX fuels. In addition to the measured isotopic compositions in fuel samples, reported measurement uncertainties, and experiment-based estimates of sample burnup, the database also provides detailed information on the fuel assembly design, including relevant geometry for reactors, assemblies, fuel rods, and samples. It also includes operational history 
data, such as irradiation history, time-dependent values for power, temperatures, void fraction, neutron poisons, and other relevant parameters as needed or as available. The primary references, which consists of original laboratory reports documenting the isotopic measurements and the fuel design and operation history, are included in the database. The Java-based graphical user interface facilitates exploration and use of the extensive information in the database. An example of SFCOMPO's embedded visualization capabilities is illustrated in Figure 1.

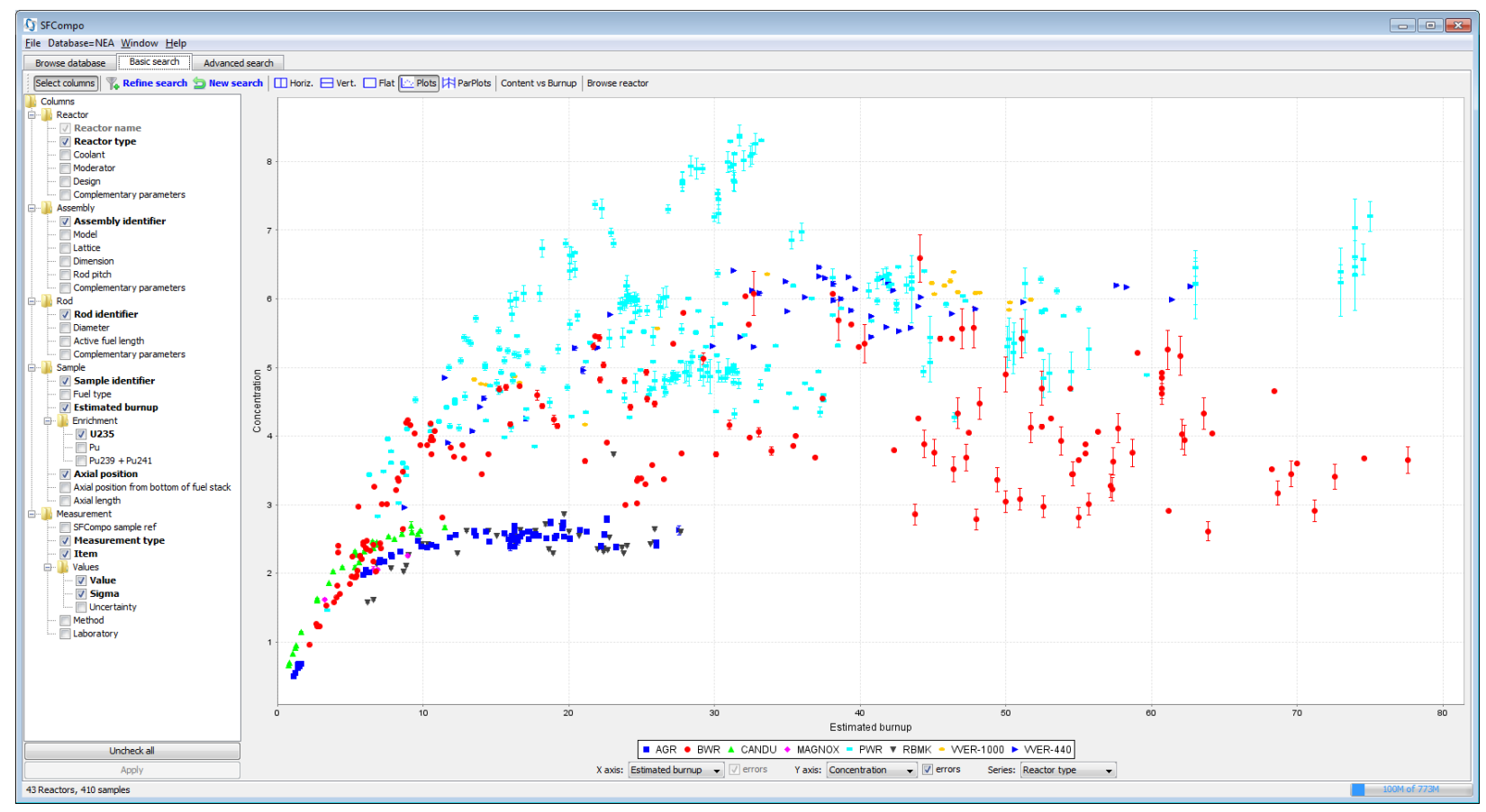

Figure 1. SFCOMPO 2.0 data visualization example: ${ }^{239} \mathrm{Pu}$ content by reactor type.

\subsection{Future Database Development}

Collection of historical data not yet captured will continue, to include additional Yankee Rowe PWR samples and additional MOX data for San Onofre PWR samples. The TRG has discussed releasing formerly proprietary data from the MALIBU program [9] for which the confidentiality period has expired. These data are of significant interest to the user community, given the high quality of the measurements, inclusion of cross-check measurements at different laboratories, and availability of data for a high-burnup sample ( $70 \mathrm{GWd} / \mathrm{MTU})$. The release and evaluation of high-burnup data would provide important support to the industry's effort to move toward higher (greater than $62 \mathrm{GWd} / \mathrm{MTU}$ ) burnup fuels. Currently the database only includes three PWR samples with burnups greater than $70 \mathrm{GWd} / \mathrm{MTU}$ from the Vandellos PWR dataset contributed by Spain. New high-burnup samples may be added in the future from an ongoing experimental program [10] at Oak Ridge National Laboratory (ORNL) that is funded by the US Department of Energy and the US Nuclear Regulatory Commission. These measurements will be performed on samples from fuel irradiated in the North Anna PWR [10]. 


\section{SFCOMPO TRG MANDATE}

The SFCOMPO TRG mission is similar to that of the well-established IRPhEP and ICSBEP TRGs under the NEA's Nuclear Science Committee, complementing their efforts and extending the applications beyond nuclear criticality safety or steady-state in-core analyses to support a broad range of fuel cycle needs, including radiological safety, source terms, shielding, or repository analyses. Given that isotopic measurements are also included within the possible scope of the IRPhEP, it is important to coordinate any activity in this area to consolidate efforts and to avoid redundancy. The first meeting of the new SFCOMPO TRG was hosted by NEA in March 2019. The meeting focused on new evaluations of spent fuel assay data from the SFCOMPO database and included discussions to plan and coordinate future TRG activities. The TRG mandate was updated to reflect the group's current focus and future plans. The revised mandate was approved by the WPNCS in July 2019 and is in effect until 2021.

The SFCOMPO TRG will continue to preserve existing data and will capture new data for isotopic measurements as they become available. Notably, the mandate was updated to expand the database's content, extending beyond the current focus on radiochemical assay data to other types of experimental spent nuclear fuel data. All TRG meeting participants expressed strong interest in adding spent fuel decay heat (calorimeter) data to the database, given its importance to the design and safety of waste management and disposal technologies. The database structure is already well suited to store this type of information. Adding new data types or identifying new parameters important to data evaluation may require updates to the database and its interface tools.

The SFCOMPO TRG will continue to preserve and archive data and original experimental reports and will facilitate distribution and dissemination of the experimental data. However, the focus is now on the independent evaluation of the existing isotopic assay data and development of benchmark models to validate depletion computational tools and their associated nuclear data. Quantifying the bias and uncertainty in the calculated isotopic compositions of irradiated fuel is essential in safety and licensing calculations for spent fuel.

\section{SFCOMPO EVALUATIONS}

\subsection{Background}

All data included in SFCOMPO 2.0 were independently reviewed to verify that the database is consistent with the primary references. This review benefited from the expertise documented in an NEA report [11] published in 2011 that summarized the state of the art in experimental spent fuel assay data and isotopic measurements methods. An NEA evaluation guide [12] published in 2016 provides recommendations from experts in the field on how to perform reviews of experimental data and how to identify and resolve potential issues or gaps in the measurement data and experimental descriptions. It also includes recommendations for deriving benchmark data and models based on available experimental data.

The next objective for the SFCOMPO TRG is to evaluate the isotopic experimental data and to develop benchmarks and benchmark models, drawing from the decades of ICSBEP and IRPhEP expertise and guidance. However, the complexity of experiments in SFCOMPO requires that different, unique facets be addressed, such as treatment of time-dependent operating data and analysis of uncertainties in modeling data (fuel design and operation history) and radiochemistry measurements.

\subsection{SFCOMPO Evaluations Status}

The draft SFCOMPO evaluations completed to date are listed in Table I. The preliminary draft evaluations were funded by Consejo de Seguridad Nuclear (CSN) in Spain $(\# 1-6,8)$ and AREVA in 
Germany (\#7). This initial effort highlighted some of the associated challenges, which are not limited to technical aspects. Significant resources and funding are required to ensure the technical rigor and high quality of the evaluations. The lessons learned from these preliminary efforts were captured in the 2016 evaluation guide [12] and have been applied to the development of the most recent 2019 evaluations. Further work on these earlier evaluations has been deferred in order to focus on completing the data compilation and developing the database that was released in 2017.

Table I. Draft SFCOMPO evaluations.

\begin{tabular}{|c|c|c|c|c|c|}
\hline \# & Title & Author(s) & $\begin{array}{c}\text { Reactor } \\
\text { Type/Fuel Type/ } \\
\text { No. Samples } \\
\end{array}$ & $\begin{array}{l}\text { Completion } \\
\text { Date }\end{array}$ & $\begin{array}{l}\text { Independent } \\
\text { Reviewers }\end{array}$ \\
\hline 1 & $\begin{array}{l}\text { Evaluation of ARIANE Experiments - } \\
\text { BEZNAU BM1 Sample Measurements }\end{array}$ & P. Ortego ${ }^{a}$ & $\mathrm{PWR} / \mathrm{MOX} / 1$ & 2011 & NA \\
\hline 2 & Evaluation of Forsmark F3F6 Experiments & C. Töre ${ }^{a}$ & $\mathrm{BWR} / \mathrm{UOX} / 1$ & 2011 & NA \\
\hline 3 & Evaluation of Dodewaard DM1Sample & P. Ortego & $\mathrm{BWR} / \mathrm{MOX} / 1$ & 2013 & NA \\
\hline 4 & Evaluation of Dodewaard DU1 Sample & P. Ortego & $\mathrm{BWR} / \mathrm{UOX} / 1$ & 2013 & NA \\
\hline 5 & $\begin{array}{l}\text { Evaluation of REBUS Measurements - } \\
\text { Sample M11 }\end{array}$ & $\begin{array}{c}\text { C. Töre and } \\
\text { A. Rodríguez } \\
\end{array}$ & PWR/UOX/1 & 2013 & NA \\
\hline 6 & Evaluation of Gösgen GU3 Samples & $\begin{array}{l}\text { C. Töre and } \\
\text { A. Rodríguez }\end{array}$ & $\mathrm{PWR} / \mathrm{UOX} / 2$ & 2014 & NA \\
\hline 7 & $\begin{array}{l}\text { Sensitivity Study and Evaluation of } \\
\text { Vandellos II Assay Data }\end{array}$ & M. Hennebach ${ }^{b}$ & PWR/UOX/9 & 2015 & NA \\
\hline 8 & $\begin{array}{l}\text { Evaluation of Beznau BM5 \& BM5' } \\
\text { Samples }\end{array}$ & $\begin{array}{l}\text { C. Töre and } \\
\text { A. Rodríguez }\end{array}$ & $\mathrm{PWR} / \mathrm{MOX} / 2$ & 2016 & NA \\
\hline 9 & $\begin{array}{l}\text { Evaluation of Fukushima-Daini-2 Samples } \\
\text { SF98 AND SF99, Assembly 2F2DN23 } \\
\text { (Type } 8 \times 8-2 \text { ) }\end{array}$ & P. Ortego & BWR/UOX/18 & 2019 & $\begin{array}{l}\text { S. Caruso } \\
\text { I. Gauld }\end{array}$ \\
\hline 10 & $\begin{array}{l}\text { Evaluation of Three Mile Island Unit } 1 \text { Fuel } \\
\text { Samples - Assemblies NJ05YU and } \\
\text { NJ070G (Type } 15 \times 15 \text { ) }\end{array}$ & G. Radulescu ${ }^{c}$ & $\mathrm{PWR} / \mathrm{UOX} / 24$ & 2019 & $\begin{array}{l}\text { A. Haghigat } \\
\text { R. Migliore }\end{array}$ \\
\hline 11 & $\begin{array}{l}\text { Evaluation of Fukushima-Daini-1 Samples } \\
\text { SF98 AND SF99, Assemblies 2F1ZN2 and } \\
\text { 2F1ZN3 (Type } 9 \times 9-9 \text { ) }\end{array}$ & U. Mertyurek ${ }^{c}$ & $\mathrm{BWR} / \mathrm{UOX} / 8$ & 2019 & $\begin{array}{l}\text { J. Bostelman } \\
\text { J. Willett } \\
\text { J }\end{array}$ \\
\hline
\end{tabular}

${ }^{a}$ SEA Ingeniería y Análisis de Blindajes S.L., Spain; ${ }^{b}$ AREVA GmbH, Germany; ${ }^{c}$ ORNL, US; ${ }^{d}$ NAGRA, Switzerland; ${ }^{e}$ Virginia Tech, US; Orano, US; ${ }^{g}$ Bostelman Engineering LLC, US.

The most recent draft evaluations (\#9-11) were funded by the US Department of Energy, and each was reviewed by two independent reviewers; the evaluations later benefited from recommendations from the experts participating in the first TRG meeting in 2019. All peer review feedback has been addressed, and the revised versions will be provided to independent reviewers and TRG members for a final check. The approval of these evaluations as NEA documents for public distribution will be discussed at the second SFCOMPO TRG meeting, which will be hosted by NEA in July 2020.

\subsection{Evaluation Process and Challenges}

To facilitate preparation of the evaluations and to enhance previous guidance [10], the SFCOMPO TRG developed a draft document template to standardize the content and format of the evaluation report and to ensure that a complete benchmark model, a sample calculation, and a global uncertainty analysis (including measurement and modeling uncertainty), would all be included. A reviewer's checklist was also developed to facilitate independent peer reviews. The template and the review checklist were used, along with the three most recent evaluations, to ensure consistency. An example of the type of content and 
level of detail included in a recent evaluation is shown in Figure 2, which shows the table of contents for the Three Mile Island 1 (TMI-1) evaluation report.

\begin{tabular}{|c|c|}
\hline$\nabla 1$ Description of the Experimental Data & $\nabla 2$ Evaluation of Experimental Data \\
\hline$\nabla 1.1$ Design Data & 2.1 Missing Data \\
\hline 1.1.1 Reactor Data & $\nabla 2.2$ Design Data \\
\hline 1.1.2 Assembly and Fuel Rod Design Data & 2.2.1 Initial UO2 Mass Density \\
\hline 1.1.3 Fuel Composition Data & 2.2.2 Gadolinia Rod Mass Density \\
\hline 1.1.4 Absorber Rod Data & 2.3 Material Compositions \\
\hline $\begin{array}{l}\text { 1.1.4 Absorber Rod Data } \\
\text { 1.1.5 Structural Material Composition Data }\end{array}$ & 2.4 Irradiation History \\
\hline $\begin{array}{l}\text { 1.1.5 Structural Material Composition Data } \\
\text { 1.1.6 Impurities }\end{array}$ & $\checkmark 2.5$ Reactor Operating Conditions \\
\hline $\begin{array}{l}\text { 1.1.6 Impurities } \\
\text { 1.1.7 Control Blade/Rod Design Data }\end{array}$ & 2.5.1 Moderator Temperature \\
\hline $\begin{array}{l}\text { 1.1.7 Control Blade/Rod Design Data } \\
\text { 1.1.8 Fuel Rod Relocation }\end{array}$ & $\begin{array}{l}\text { 2.5.2 Specific Power } \\
\nabla 2.6 \text { Sample Burnup Analysis }\end{array}$ \\
\hline $\begin{array}{l}\text { 1.1.8 Fuel Rod Relocation } \\
\nabla \text { 1.2 Reactor Operating History Data }\end{array}$ & 2.6.1 Error Propagation to Sample Burnup by the $148 \mathrm{Nd}$ Method \\
\hline $\begin{array}{l}\text { 1.2.1 Cycle Dates } \\
\text { 1.2 Reactor Operatıng History Data }\end{array}$ & 2.7 Additional Data Verification \\
\hline $\begin{array}{l}\text { 1.2.1 Cycle Dates } \\
1.2 .2 \text { Power History }\end{array}$ & $\nabla 3$ Benchmark Specifications \\
\hline $\begin{array}{l}\text { 1.2.2 Power History } \\
\text { 1.2.3 Temperatures }\end{array}$ & 3.1 Assembly and Fuel Rod Design Data \\
\hline & 3.2 Material and Temperature Data \\
\hline & $\checkmark$ 3.3 Reactor Operating History Data \\
\hline & 3.3.1 Cycle Dates \\
\hline $\begin{array}{l}\text { 1.2.6 Absorber Rods and Control Blades } \\
\text { 1.2.7 Neighboring Assemblies }\end{array}$ & 3.3.3 Soluble Boron \\
\hline $\begin{array}{l}\text { 1.2.7 Neighboring Assemblies } \\
\nabla \text { 1.3 Fuel Sample Data }\end{array}$ & 3.3.4 Specific Power \\
\hline & 3.4 Reactor Operating Conditions \\
\hline $\begin{array}{l}\text { 1.3.1 Fuel Rod Uranium Loadings } \\
\text { 1.3.2 Sample Temperature Data }\end{array}$ & 3.5 Measured Isotopic Concentrations \\
\hline $\begin{array}{l}\text { 1.3.2 Sample Temperature Data } \\
\text { 1.3.3 Moderator Density Data }\end{array}$ & $\nabla 4$ Uncertainty Analysis \\
\hline $\begin{array}{l}\text { 1.3.3 Moderator Density Data } \\
\text { 1.3.4 Fuel Rod Burnup Data }\end{array}$ & $\begin{array}{l}\text { 4.1 Code and Nuclear Data Library } \\
\text { 4.2 Parameters and Parameter Uncertainty Values }\end{array}$ \\
\hline $\begin{array}{l}\text { 1.3.4 Fuel Rod Burnup Data } \\
\nabla \text { 1.4 Measurement Data }\end{array}$ & $\begin{array}{l}\text { 4.2 Parameters and Parameter Uncertainty Values } \\
\text { 4.3 Individual Parameter Uncertainty Results }\end{array}$ \\
\hline & $\begin{array}{l}4.3 \text { Individual Parameter Uncertainty Results } \\
4.4 \text { Total Uncertainty Results }\end{array}$ \\
\hline $\begin{array}{l}\text { 1.4.1 ANL Measurements } \\
\text { 1.4.2 GE-VNC Measurements }\end{array}$ & $\checkmark 5$ Results of Sample CalcuLations \\
\hline $\begin{array}{l}\text { 1.4.2 GE-VNC Measurements } \\
\text { 1.4.3 ORNL Measurements }\end{array}$ & 5.1 Codes and Nuclear Data Libraries \\
\hline $\begin{array}{l}\text { 1.4.3 ORNL Measurements } \\
\nabla \text { 1.4.4 Unit Conversion }\end{array}$ & 5.2 Triton 2D Geometry Models \\
\hline $\begin{array}{l}\text { 1.4.4 Unit Conversion } \\
\text { 1.4.4.1 Nuclear Data }\end{array}$ & 5.3 Comparison of Sample Calculations and Measurements \\
\hline $\begin{array}{l}\text { 1.4.4.1 Nuclear Data } \\
\text { 1.4.4.2 Conversion from } \mathrm{g} / \mathrm{g} 238 \mathrm{Umeasured} \mathrm{to} \mathrm{g} / \mathrm{g} \text { Uinitial }\end{array}$ & $\begin{array}{l}5.4 \text { Burnup Normalization Matching Measured } 148 \mathrm{Nd} \text { Concentrations } \\
6 \text { References }\end{array}$ \\
\hline $\begin{array}{l}\text { 1.4.4.2 Conversion from } \mathrm{g} / \mathrm{g} 238 U \text { measured to } \mathrm{g} / \mathrm{g} \text { Uinitial } \\
\text { 1.4.4.3 Conversion from } \mathrm{Ci} / \mathrm{g} \text { Uinitial to } \mathrm{g} / \mathrm{g} \text { Uinitial }\end{array}$ & APPENDIX A: Typical Input Listing \\
\hline 1.4.4.3 Conversion from Ci/guinitial to $\mathrm{g} / \mathrm{g}$ Uinitial & APPENDIX B: Analysis of Uncertainty Associated with Neglecting the \\
\hline
\end{tabular}

Figure 2. Evaluation report content example (for TMI-1 evaluation \#10, specified in Table I).

Uncertainty analysis presents a challenge for SFCOMPO experimental data evaluation. As compared to uncertainty quantification for steady-state criticality experiments, the major difference in this case is the uncertainty treatment for time-dependent parameters in the benchmark model, such as power or burnup history, moderator condition, or fuel temperature history. Moreover, the measurement data consist of many metrics ( $\mathrm{k}_{\text {eff }}$ or reaction rates for criticality evaluations), including a large set of isotope concentrations (e.g., over 50 isotopes for the TMI-1 dataset). The uncertainty in these complex radiochemical analysis measurements is notoriously challenging for measurement laboratories to estimate. There is a general tendency to underestimate uncertainty, as observed during interlaboratory comparisons. Each isotope has a different sensitivity to fuel design or uncertainties in the operating history parameters, and each isotope exhibits a different variation with burnup.

Because of differences in system characteristics and physics behaviors, the types of parameters in the benchmark model to be considered in the uncertainty analysis depend on the reactor type. For example, the modeling parameters considered in uncertainty analysis for the PWR TMI-1 samples include characteristics for fuel (density, enrichment, impurity content, pellet diameter, diameter changes due to densification/swelling), cladding (thickness), water moderator (density, temperature, soluble boron content) and fuel sample history (burnup). Additional modeling parameters were considered for BWR 
sample uncertainties in the Fukushima-Daini-2 data evaluation, such as void fraction, axial power history, gap closure, or channel bow. For many of the operating parameters, the values are not measured directly, so they must be estimated using calculations performed by the reactor operator or another qualified expert. These parameters include for example fuel temperature, pellet diameter, cladding diameter, and moderator density. Similarly, the uncertainties in these parameters usually must be estimated based on independent studies or expert judgement. This challenging process provides important information and identifies key parameters that may drive the observed deviations between measurements and calculations.

Overall, fuel sample burnup is the most significant modeling parameter for the isotopes in the experimental assays, and uncertainty in sample burnup drives the uncertainties in many of the calculated isotopic concentrations. The reported sample burnups available from experimental reports were usually estimated based on measured data for burnup indicator fission products and are therefore affected by the isotopes' measurement uncertainties. In most cases, the reported sample burnups are based on measurements for ${ }^{148} \mathrm{Nd}$, which is widely used as a burnup indicator and serves as the basis for the ASTM E321 standard method for burnup determination. In these cases, sample burnup uncertainties are correlated to ${ }^{148} \mathrm{Nd}$ measurement uncertainties, and they can vary significantly from one dataset to another. For example, for the TMI-1 dataset, the relative measurement uncertainty $(1 \sigma)$ for ${ }^{148} \mathrm{Nd}$ varies between 1.5 and $7.1 \%$.

As an example of the computational uncertainty due to all considered modeling parameter uncertainties, which are assumed to be uncorrelated, the values determined for one of the TMI- 1 samples $(22.8$ $\mathrm{GWd} / \mathrm{MTU}$ burnup and $1.5 \%$ sample burnup uncertainty) and selected isotopes are $1.1 \%$ for ${ }^{235} \mathrm{U}, 2.4 \%$ for ${ }^{239} \mathrm{Pu}, 2.0 \%$ for ${ }^{149} \mathrm{Sm}$, and $8.8 \%$ for ${ }^{244} \mathrm{Cm}$. The measurement uncertainty and computational uncertainty due to modeling parameters are assumed to be independent and are combined into a total uncertainty for each isotope. For the example shown here, the total uncertainty is $1.2 \%$ for ${ }^{235} \mathrm{U}, 2.5 \%$ for ${ }^{239} \mathrm{Pu}, 2.2 \%$ for ${ }^{149} \mathrm{Sm}$, and $9.3 \%$ for ${ }^{244} \mathrm{Cm}$.

\section{CONCLUSIONS}

The SFCOMPO database, the world's largest public resource for measured spent fuel isotopic assay data, continues to expand and improve through the concerted contributions of the international community. The next objectives in the effort to provide practical information of the highest value to end users are (1)evaluate the isotopic experimental data and (2) develop the benchmark and benchmark models for validating depletion computational tools and associated nuclear data. Under the direction of NEA's Nuclear Science Committee/WPNCS, the SFCOMPO TRG has been mandated to lead these activities. Drawing from expertise and experience of the former EGASNDF group and from the well-established ICSBEP and IRPhEP TRGs, this new group has diligently engaged in developing evaluation reports and benchmarks and addressing the specific challenges associated with these evaluations.

\section{ACKNOWLEDGMENTS}

The authors would like to acknowledge the funding provided for this work by the Office of Nuclear Energy within the US Department of Energy. The continuous support of SFCOMPO by the Nuclear Energy Agency's Working Party on Nuclear Criticality Safety is much appreciated and acknowledged. Past development of SFCOMPO would not have been possible and successful without the valuable contributions of numerous experts from diverse institutions in many countries. Special thanks are extended to all of them for their dedication and the high quality of their work, as well as for their enthusiasm in continuing to contribute to the future of the SFCOMPO. 


\section{REFERENCES}

1. OECD-NEA, "SFCOMPO 2.0. Database of Measured Isotopic Concentrations of Spent Nuclear Fuel, with Operational Histories and Design Data," https://www.oecd-nea.org/sfcompo/ (2017).

2. F. Michel-Sendis et al., "SFCOMPO-2.0: An OECD NEA Database of Spent Nuclear Fuel Isotopic Assays, Reactor Design Specifications, and Operating Data," Annals of Nuclear Energy 110, pp. 779-788. https://doi.org/10.1016/j.anucene.2017.07.022 (2017).

3. S. Tsuda et al., "Status of the NEA International Activities on Nuclear Criticality Safety," Proceedings of the International Conference on Nuclear Criticality Safety (ICNC 2019), Paris, France (2019).

4. OECD-NEA, "International Reactor Physics Experiment Evaluation (IRPhE) Project" https://www.oecd-nea.org/science/wprs/irphe/ (2019)

5. J.D. Bess, T. Ivanova, I. Hill, and M.A. Marshall, "The 2018 Edition of the IRPhEP Handbook," INL/CON-17-43940-Revision-0, Idaho National Laboratory https://www.osti.gov/servlets/purl/1478327 (2018).

6. J. B. Briggs, L. Scott, and A. Nouri, "The International Criticality Safety Benchmark Evaluation Project," Nuclear Science and Engineering 145(1), pp. 1-10 (2003). https://doi.org/10.13182/NSE03-14

7. F. Michel-Sendis, I. Gauld, M. Bossant, and N. Soppera, "A New OECD/NEA Database of Nuclide Compositions of Spent Nuclear Fuel," Proceedings of the International Conference on Physics of Reactors (PHYSOR 2014), Kyoto, Japan (2014).

8. I. Gauld, M.L. Williams, F. Michel-Sendis, and J.S. Martinez, "Integral Nuclear Data Validation Using Experimental Spent Nuclear Fuel Compositions," Nuclear Engineering and Technology 49(6), pp. 1226-1233. https://doi.org/10.1016/j.net.2017.07.002 (2017).

9. D. Boulanger et al., "High Burnup PWR and BWR MOX Fuel Performance: A Review of Belgonucleaire Recent Experimental Programs," CD, Proceedings of the 2004 International Meeting on LWR Fuel Performance, Orlando, Florida, USA (2004).

10. R. Montgomery, R.N. Morris, B. Bevard, and J. Scaglione, "Key Results from Detailed Nondestructive Examinations of 25 Pressurized Water Reactor High Burnup Spent Nuclear Fuel Rods," Nuclear Science and Engineering 193 (8), pp. 884-902. https://doi.org/10.1080/00295639.2019.1573602 (2019).

11. NEA, "Spent Nuclear Fuel Assay Data for Isotopic Validation (State-of-the-Art Report)," NEA/NSC/WPNCS/DOV(2011)5 https://www.oecd-nea.org/science/wpncs/ADSNF/SOAR_final.pdf (2011).

12. NEA, "Evaluation Guide for the Evaluated Spent Nuclear Fuel Assay Database (SFCOMPO)," NEA/NSC/R(2015)8, Nuclear Energy Agency. https://www.oecd-nea.org/science/docs/2015/nsc-r2015-8.pdf (2016). 